\title{
The burden of extended-spectrum $\beta$-lactamase-producing Enterobacteriaceae in patients with cirrhosis
}

\author{
Richard Moreau
}

Received: 10 June 2014/ Accepted: 21 July 2014/Published online: 6 September 2014

(C) Asian Pacific Association for the Study of the Liver 2014

Patients with cirrhosis have high susceptibility to bacterial infections [1]; $24 \%$ of patients admitted to the hospital for an acute decompensation of cirrhosis have bacterial infection [2]. The most common infection is spontaneous bacterial peritonitis (SBP) [1, 2]. It is well known that SBP is caused by Gram-negative bacteria such as Escherichia coli or Klebsiella pneumoniae originating from the intestinal lumen [3]. The translocation of intestinal bacteria is a crucial step in the process leading to SBP $[1,4]$. Little is known about underlying mechanisms that explain bacterial translocation [4].

During the last 30 years the mortality of SBP has decreased from 70 to $30 \%$ [3]. This was the result of large use of a strategy which includes high index of suspicion leading to diagnosis paracentesis, diagnosis of SBP based on neutrophil count $\geq 250 / \mathrm{mL}$ in the ascitic fluid and subsequent rapid initiation (before results of culture) of wide spectrum, non-nephrotoxic antibiotics (e.g., third generation cephalosporins) against Enterobacteriaceae (E. coli, K. pneumonia) which are the most common causes

R. Moreau ( $\square)$

Inserm UMR_S 1149, Centre de Recherche sur l'Inflammation (CRI), Inserm et Université Paris-Diderot, Paris 7 - Site Bichat, 16 Rue Henri Huchard, 75890 Paris Cedex 18, France e-mail: Richard.moreau@inserm.fr

\section{R. Moreau}

Faculté de Médecine, Université Paris Diderot, Paris, France

R. Moreau

Service d'Hépatologie, Département Hospitalo-Universitaire (DHU) UNITY, Hôpital Beaujon, AP-HP, Clichy, France

R. Moreau

Laboratoire d'Excellence (Labex) Inflamex, PRES Sorbonne

Paris Cité, Paris, France of SBP [3]. In the late 1990s mortality of SBP was further decreased to $10 \%$ with the combined use of empiric antibiotics and the intravenous administration of human albumin [5]. This beneficial effect was related to a significant decrease in the development of kidney failure (known as hepatorenal syndrome, HRS) [5]. Today, SBP remains the most common trigger of infection-induced acute-onchronic liver failure (ACLF) [2]. ACLF whichever its trigger, is characterized by the failure(s) of organs (including kidney, cerebral, liver, coagulation, circulation and lungs) and high risk of death depending on the number of failing organs [2].

Due to the severity of SBP, efforts have been made to prevent this complication. In patients who survive an episode of SBP long-term prophylaxis with the fluoroquinolone norfloxacin significantly decreases the risk of recurrent SBP [3]. The impact on survival is unknown. In patients with low ascitic fluid protein levels $(<1.5 \mathrm{~g} / \mathrm{dL})$ but without a prior episode of SBP the efficacy of primary prophylaxis using a fuoroquinolone is still unclear. One trial has shown that norfloxacin significantly decreased the risk for developing a first episode of SBP [6], a finding that was not confirmed in another trial with ciprofloxacin [7].

Recently, an increasing number of cases of SBP due to extended spectrum $\beta$-lactamase (ESBL)-producing E. coli, $K$. pneumonia have been reported in Asia [8-11] and Europe [12-16]. Some risk factors for SBP caused by ESBL-producing bacteria Enterobacteriaceae have been identified including the in-hospital acquisition of infection [10-15], long-term norfloxacin prophylaxis [13], use of $\beta$ lactams within the last 3 months [13], and infection by multiresistant bacteria in the last 6 months [13]. ESBLproducing strains are resistant not only to third-generation cephalosporins, amoxicillin-clavulanic acid but also to quinolones and trimethoprim-sulfamethoxazole [13]. 
ESBL-producing strains are usually sensitive to carbapenems although some cases have reported of carbapenemaseproducing Enterobacteriacea [16]. In any case, these findings indicate that international recommendations stating that third-generation cephalosporins or amoxicillinclavulanic acid are the empiric antibiotics of choice for SBP [3] and are inappropriate for SBP episodes caused by ESBL-producing bacteria. Finally, studies have shown that SBP episodes due to ESBL-producing bacteria are more severe than episodes caused by strains sensitive to recommended empiric antibiotics [10-14]. The reasons for the severity of infections due to ESBL-producing bacteria are unknown; theoretically, poor prognosis may be related to a greater severity of the underlying liver disease, higher prevalence of septic shock, or delayed initiation of appropriate antibiotics.

In this issue of Hepatology International Kim et al. [17] report results of a retrospective analysis conducted in 231 patients with SBP due to E. coli or K. pneumonia of which 52 were caused by ESBL-producing strains. This study confirms that SBP caused by ESBL-producing strains are more severe than those due to other bacteria, whereby morality at day-7 and day-30 was 21.2 vs. $10.1 \%$ $(p=0.03)$ and 34.6 vs. $18.4 \%(p=0.01)$, respectively. As expected [13], infections due to ESBL-producing bacteria were more frequently hospital-acquired. Interestingly, the severity of cirrhosis and the prevalence of septic shock were not higher in the "ESBL group" than in the "nonESBL group". The proportion of patients who received appropriate antibiotics during the first 3 days was significantly lower in the ESBL group (48.1 vs. $100 \%$ ) indicating a delay in the initiation of effective antibiotics. Finally, Kim et al. [17] compared risk factors for 30-day mortality between the two groups and identified two independent predictors of death that were specific for the "ESBL group", i.e., the presence of HCC and the presence of bacteremia. The finding of HCC as a predictor of death is not surprising as liver cancer per se is known to drive severity. Delayed initiation of the appropriate antibiotics may be associated with increased bacterial burden, bacteremia, dissemination of infection and subsequent poor prognosis.

Although the study by Kim et al. did not investigate the cause of patients' death, it is well established that ACLF is the major mechanism [2]. Nevertheless an important question that remains to be addressed is the mechanisms of ACLF triggered by infections due to ESBL-producing bacteria. A first hypothesis is that "persistent" infection may elicit an excessive immune response of the host resulting in cytokine storm and subsequent tissue damage [1]. There is some evidence that some patients with cirrhosis have an excessive proinflammatory response of innate immune cells to bacterial components [18-20].
Alternatively the dissemination of infection may result in tissue damage because bacteria express virulence factors with deleterious cell effects (e.g., alterations in homeostasis of endoplasmic reticulum or mitochondria; impairment of the induction of tissue repair program) [21]. Future studies should address these points.

The severity of infections due to ESBL-producing bacteria raises the question of how to initiate quickly the appropriate antibiotics. Obviously one needs to have new techniques for rapid diagnosis of these infections. Patients with decompensated cirrhosis are hospitalized very often and it could be useful to perform systematically rectal swabs in order to identify carriers of ESB-producing bacteria. Finally it should be emphasized that there is no established primary or secondary prophylaxis for these infections.

How can we treat an episode of SBP? International recommendations remain appropriate for patients with community-acquired SBP who do not have risk factors of infections caused by ESBL-producing strains; in these patients, third-generation cephalosporins or amoxicillinclavulanic acid can be used as first-line wide-spectrum empiric antibiotics [3]. Patients with hospital-acquired SBP are at risk of infection caused by ESBL-producing bacteria. There are no international recommendations regarding empiric antibiotics in these patients. In our Liver Unit the strategy depends on whether or not the patient is known to carry ESBL-producing bacteria. When the patient is known to carry these bacteria the first treatment option for hospital-acquired SBP is the administration of piperacillin and tazobactam. When the carriage status is unknown we treat the episode of SBP with a carbapenem. We also attempt to perform swabs seeking for carriage of ESBL-producing strains in patients who are in frequent contact with the health care system and who fulfill the following criteria: on the waiting list, any admission for an acute decompensation of cirrhosis, refractory ascites treated by repeated largevolume paracentesis, use of long-term antibiotic prophylaxis. Since there are ten studies [22-31] and one metaanalysis [32] showing that the use of proton-pump inhibitors increases the risk of developing SBP, PPI administration should not be recommended, at least in patients with ascites.

Conflict of interest Richard Moreau declares that he has no conflict of interest.

\section{References}

1. Gustot T, Durand F, Lebrec D, Vincent JL, Moreau R. Severe sepsis in cirrhosis. Hepatology. 2009;50:2022-2033

2. Moreau R, Jalan R, Gines P, Pavesi M, Angeli P, Cordoba J, et al. Acute-on-chronic liver failure is a distinct syndrome that 
develops in patients with acute decompensation of cirrhosis. Gastroenterology 2013;144:1426-1437

3. European Association for the Study of the Liver. EASL clinical practice guidelines on the management of ascites, spontaneous bacterial peritonitis, and hepatorenal syndrome in cirrhosis. J Hepatol 2010;53:397-417

4. Jalan R, Fernandez J, Wiest R, Schnabl B, Moreau R, Angeli P, et al. Bacterial infections in cirrhosis: a position statement based on the EASL Special Conference 2013. J Hepatol. 2014;60:1310-1324

5. Sort P, Navasa M, Arroyo V, Aldeguer X, Planas R, Ruiz-delArbol L, et al. Effect of intravenous albumin on renal impairment and mortality in patients with cirrhosis and spontaneous bacterial peritonitis. N Engl J Med. 1999;341:403-409

6. Fernández J, Navasa M, Planas R, Montoliu S, Monfort D, Soriano $\mathrm{G}$, et al. Primary prophylaxis of spontaneous bacterial peritonitis delays hepatorenal syndrome and improves survival in cirrhosis. Gastroenterology. 2007;133:818-824

7. Terg R, Fassio E, Guevara M, Cartier M, Longo C, Lucero R, et al. Ciprofloxacin in primary prophylaxis of spontaneous bacterial peritonitis: a randomized, placebo-controlled study. J Hepatol. 2008;48:774-779

8. Park YH, Lee HC, Song HG, Jung S, Ryu SH, Shin JW, et al. Recent increase in antibiotic-resistant microorganisms in patients with spontaneous bacterial peritonitis adversely affects the clinical outcome in Korea. J Gastroenterol Hepatol. 2003;18:927-933

9. Kang CI, Kim SH, Park WB, Lee KD, Kim HB, Oh MD, et al. Clinical outcome of bacteremic spontaneous bacterial peritonitis due to extended-spectrum beta-lactamase-producing Escherichia coli and Klebsiella pneumoniae. Korean J Intern Med. 2004;19:160-164

10. Song JY, Jung SJ, Park CW, Sohn JW, Kim WJ, Kim MJ, et al. Prognostic significance of infection acquisition sites in spontaneous bacterial peritonitis: nosocomial versus community acquired. J Korean Med Sci. 2006;21:666-671

11. Cheong HS, Kang CI, Lee JA, Moon SY, Joung MK, Chung DR, et al. Clinical significance and outcome of nosocomial acquisition of spontaneous bacterial peritonitis in patients with liver cirrhosis. Clin Infect Dis. 2009;48:1230-1236

12. Merli M, Lucidi C, Giannelli V, Giusto M, Riggio O, Falcone M, et al. Cirrhotic patients are at risk for health care-associated bacterial infections. Clin Gastroenterol Hepatol. 2010;8:979-985

13. Fernandez J, Acevedo J, Castro M, Garcia O, de Lope CR, Roca $\mathrm{D}$, et al. Prevalence and risk factors of infections by multiresistant bacteria in cirrhosis: a prospective study. Hepatology. 2012;55:1551-1561

14. Ariza X, Castellote J, Lora-Tamayo J, Girbau A, Salord S, Rota $\mathrm{R}$, et al. Risk factors for resistance to ceftriaxone and its impact on mortality in community, healthcare and nosocomial spontaneous bacterial peritonitis. J Hepatol. 2012;56:825-832

15. Alexopoulou A, Papadopoulos N, Eliopoulos DG, Alexaki A, Tsiriga A, Toutouza $\mathrm{M}$, et al. Increasing frequency of grampositive cocci and gram-negative multidrug resistant bacteria in spontaneous bacterial peritonitis. Liver Int. 2013;33:975-981

16. Piano S, Romano A, Rosi S, Gatta A, Angeli P. Spontaneous bacterial peritonitis due to carbapenemase-producing Klebsiella pneumoniae: the last therapeutic challenge. Eur J Gastroenterol Hepatol. 2012;24:1234-1237

17. Kim MJ, Song K-H, Kim N-H, Choe PG, Park WB, Bang JH, et al. Clinical outcomes of spontaneous bacterial peritonitis due to extended-spectrum beta-lactamase-producing Escherichia coli or
Klebsiella pneumoniae: a retrospective cohort study. Hepatol Int 2014. doi:10.1007/s12072-014-9543-7

18. Tazi KA, Quioc JJ, Saada V, Bezeaud A, Lebrec D, Moreau R. Upregulation of TNF-alpha production signaling pathways in monocytes from patients with advanced cirrhosis: possible role of Akt and IRAK-M. J Hepatol. 2006;45:280-289

19. Coant N, Simon-Rudler M, Gustot T, Fasseu M, Gandoura S, Ragot K, et al. Glycogen synthase kinase 3 involvement in the excessive proinflammatory response to LPS in patients with decompensated cirrhosis. J Hepatol. 2011;55:784-793

20. Gandoura S, Weiss E, Rautou PE, Fasseu M, Gustot T, Lemoine $\mathrm{F}$, et al. Gene- and exon-expression profiling reveals an extensive LPS-induced response in immune cells in patients with cirrhosis. J Hepatol. 2013;58:936-948

21. Medzhitov R, Schneider DS, Soares MP. Disease tolerance as a defense strategy. Science. 2012;335:936-941

22. Campbell MS, Obstein K, Reddy KR, Yang YX. Association between proton pump inhibitor use and spontaneous bacterial peritonitis. Dig Dis Sci. 2008;53:394-398

23. Bajaj JS, Zadvornova Y, Heuman DM, Hafeezullah M, Hoffmann RG, Sanyal AJ, et al. Association of proton pump inhibitor therapy with spontaneous bacterial peritonitis in cirrhotic patients with ascites. Am J Gastroenterol. 2009;104:1130-1134

24. Bajaj JS, Ananthakrishnan AN, Hafeezullah M, Zadvornova Y, Dye A, McGinley EL, et al. Clostridium difficile is associated with poor outcomes in patients with cirrhosis: a national and tertiary center perspective. Am J Gastroenterol. 2010;105:106-113

25. Choi EJ, Lee HJ, Kim KO, Lee SH, Eun JR, Jang BI, et al. Association between acid suppressive therapy and spontaneous bacterial peritonitis in cirrhotic patients with ascites. Scand $\mathrm{J}$ Gastroenterol. 2011;46:616-620

26. Jamil S, Ahmed S, Memon A, Masood S, Ali Shah SH, Hamid SS, et al. Factors predicting the recurrence of spontaneous bacterial peritonitis in patients with cirrhosis. J Coll Physicians Surg Pak 2011;21:407-410

27. Goel GA, Deshpande A, Lopez R, Hall GS, van Duin D, Carey WD. Increased rate of spontaneous bacterial peritonitis among cirrhotic patients receiving pharmacologic acid suppression. Clin Gastroenterol Hepatol. 2012;10:422-427

28. Bajaj JS, Ratliff SM, Heuman DM, Lapane KL. Proton pump inhibitors are associated with a high rate of serious infections in veterans with decompensated cirrhosis. Aliment Pharmacol Ther. 2012;36:866-874

29. de Vos M, De Vroey B, Garcia BG, Roy C, Kidd F, Henrion J, et al. Role of proton pump inhibitors in the occurrence and the prognosis of spontaneous bacterial peritonitis in cirrhotic patients with ascites. Liver Int. 2013;33:1316-1323

30. Miura K, Tanaka A, Yamamoto T, Adachi M, Takikawa H. Proton pump inhibitor use is associated with spontaneous bacterial peritonitis in patients with liver cirrhosis. Intern Med. 2014;53:1037-1042

31. Merli M, Lucidi C, Di Gregorio V, Giannelli V, Giusto M, Ceccarelli $\mathrm{G}$, et al. The chronic use of beta-blockers and proton pump inhibitors may affect the rate of bacterial infections in cirrhosis. Liver Int 2014. doi:10.1111/liv.12593

32. Trikudanathan G, Israel J, Cappa J, O'Sullivan DM. Association between proton pump inhibitors and spontaneous bacterial peritonitis in cirrhotic patients-a systematic review and meta-analysis. Int J Clin Pract. 2011;65:674-678 